ASIAN JOURNAL OF MANAGEMENT STUDIES

Journal homepage: https://www.sab.ac.lk/ajms/

Faculty of Management Studies Sabaragamuwa University of Sri Lanka

\title{
The Technical Efficiency of Small-scale Tea Plantation in Sri Lanka
}

\section{DGM Jeewanthi and AA Shantha}

Department of Economics and Statistics, Faculty of Social Sciences and Languages, Sabaragamuwa University of Sri Lanka

\begin{abstract}
The tea smallholding sector is the leader in national tea production in Sri Lanka. However, it is believed that increasing profit is very difficult without increasing costly inputs, considering the high cost of production. This paper investigates the technical efficiency of smallholder tea farmers (STFs) in Sri Lanka by employing stochastic production frontier using a sample of 120 STFs. The results showed that the average technical efficiency of selected STFs is 78.44 per cent. This indicates that output can be further increased by 21.56 per cent without increasing the level of input. Gender and access to quality extension services were identified as the variables that have the greatest impact on technical efficiency. The results further showed the labour is the most important factor for tea production.
\end{abstract}

Keywords: Frontier Production Function, Smallholder Tea Farmers, Tea Production, Technical Efficiency
(C) Faculty of

Management Studies

Sabaragamuwa

University of Sri Lanka

ARTICLE INFO

Article history:

Received: 13 November 2020

Accepted: 07 January 2021

Published: 09 February 2021

E-mail Address:

madhushikajeewanthi45@gmail.com arunaeconomics999@gmail.com 


\section{INTRODUCTION}

The tea plant, scientifically known as "Camellia Sinensis", is considered as endemic to India. Tea cultivation was introduced to Sri Lanka in 1867 during the colonial period by James Taylor. Tea is one of the major commercial crops in Sri Lanka, and since then, tea has been popular all over the world as Ceylon Tea (Mohamed \& Zoysa, 2006). Tea industry has been recognized as a dynamic sector economic development in Sri Lanka. The tea industry significantly contributes to the Sri Lankan economy through various economic aspects such as foreign exchange earnings, GDP, employment and consumption. National tea production in 2019 with 300.1 million $\mathrm{Kg}$, contributing $10 \%$ to the value-added of agriculture and $0.7 \%$ to GDP compared to other sectors of the economy and $11.3 \%$ of the total export income (CBSL, 2019). Further, it employs an estimated 1.5 million people (CBSL, 2016).

The structural changes in the tea production sector in Sri Lanka began in the 1950s, and as a result, the tea smallholdings sector has come forward quantitatively and qualitatively. The highest quality tea is introduced to the market by the STFs, with a contribution of $75.4 \%$ to the total tea production in Sri Lanka (CBSL, 2017). There are several definitions for small scale tea lands in Sri Lanka, and tea lands less than 10 acres are considered "small scale tea lands" under the Tea Control Act. The total area under tea cultivation is 221,968 hectares, the smallholding sector and the large estate sector cover 132,329 hectares $(59 \%)$ and 89,639 hectares (41\%) respectively (TSHDA, 2017).

At present, the tea smallholding sector is spread over 3,692 Grama Niladhari Divisions and 123 Divisional Secretariat Divisions in fourteen districts in Upper, Middle and Low country. It represents $10 \%$ of the total population of Sri Lanka. According to the Small Scale Tea Land Census in 2005, the total area of tea smallholding without abandoned tea lands is estimated as 125,019 hectares. Of the small scale tea land area, 113,190 acres (34.6\%) are less than one acre, and 198,707 acres (60.8\%) are less than two acres. The extent of small tea lands over 10 acres are 59,731 acres, and 267,253 acres are tea lands less than 10 acres (TSHDA, 2017). 
The large tea estates are dominated by Upper and Middle country. The districts with the largest number of STFs (75\% of the size) and the largest number of small scale tea land areas are Ratnapura, Galle and Matara respectively. The number of STFs and the extent of small tea lands in those districts are 92,038, 81,491, 63,273 and 97,984, 90,524, 67,613 hectares respectively (TSHDA, 2017). The number of low country STFs in 2015 was 397,223 , and $74 \%$ of STFs are less than 1 acre and $93 \%$ of STFs are less than 2 acres (Fernando, 2016).

Tea production and average productivity in tea smallholding sector in 2017 were 232.417 million $\mathrm{Kg}$ and $1,995 \mathrm{Kg}$ per hectare. It has also contributed Rs. 1,438 billion to foreign exchange. The low country region has contributed $77 \%$ and $64 \%$ to the small tea land and GDP respectively. Tea varieties (clones) used in the low country of Sri Lanka can be identified as TRI 2021, 2022, 2023, 2025, 2026, 2027, 2043, 2045, CW21, DG-39, MT-18, MT5, MT-106, H 1/158 and KEN 16/3. According to the Sri Lanka Tea Market Prices in 2017, the average price received per $\mathrm{Kg}$ of Upper, Middle and Low country green tea leaves was Rs. 90.69. At the end of 2017, the number of registered Tea Smallholdings Development Societies were 1,435, and the number of members was 329,778. The area of small tea lands in Matara district is 22,971 hectares, and the productivity is $1,622 \mathrm{Kg}$ of tea leaves per hectare (TSHDA, 2017).

Previous studies related to the tea smallholding sector in Sri Lanka have identified barriers that largely reflect productivity and technology. Samaraweera et al. (2013) studied the problems of tea smallholding in Sri Lanka and found that there was a very low level of technical understanding among STFs. The researcher Fernando (2016) identified several major obstacles to the growth of tea smallholding including unsecured price, narrowing of profit margin, low rate of reinvestment, labour shortage, poor access roads, facing adverse weather conditions and land degradation. CBSL (2019) indicates that tea production in 2019 was decreased $1.3 \%$ compared to 2018 due to lower productivity, high cost of production, labour issues, declining value-added exports, poor tea leaf plucking practices, global market price fluctuations and low quality. Also, the average price per $\mathrm{kg}$ of tea at the Colombo Tea Auction has dropped, and the cost of producing tea has increased by $1.8 \%$. Tea replanting and new planting decreased by $37.9 \%$ and $32 \%$ respectively. Low country tea production, which contributed $63 \%$ to the total tea production and has many STFs, has declined by $9.3 \%$ in 2019. 
According to TSHDA (2017), the problems in the tea smallholding sector are the shortage of labour for tea leaf plucking, pruning, weeding and regional wage disparities. Furthermore, in tea smallholding, the price of green tea has been steadily rising in recent years, the average cost of production per $\mathrm{Kg}$ of tea leaves in 2015, 2016 and 2017 were Rs. 55.08, Rs. 64.52 and Rs. 71.65 respectively. Also, the high labour cost of replanting tea due to labour shortages and the reduction in the amount of financial subsidy covered by the fertilizer subsidy have contributed to the increase in cultivation costs. It is estimated that $83 \%$ of the total cost is incurred as labour cost. Although the number of newly registered societies increased by 32 in 2017 compared to 2016 , the membership of the societies has decreased by $3 \%$. The decline in the number of programs implemented through societies such as the fertilizer subsidy scheme and the reluctance of some STFs to renew their membership has led to a decline in membership.

Production efficiency is an important criterion for the future of the local tea industry, considering the growing competition in the world tea market and the high cost of production. Furthermore, measuring the efficiency (technical, allocative and economic) of developed and developing countries remains an important field of research, especially in developing agricultural economies where resources are scarce and opportunities to develop and use better technologies are dwindling (Tadesse \& Krishnamoorthy,1997). According to the Ali and Chaudhry (1990) efficiency measurement is critical as it is a factor that contributes to productivity growth.

Although studies have been conducted on measuring the technical efficiency of small scale tea plantations in foreign countries, there is a lack of studies on measuring the technical efficiency of small scale tea plantations in Sri Lanka. Also, there is a severe shortage of studies on measuring the technical efficiency of the small scale tea plantation in Matara district, which has the third-largest number of STFs out of 25 districts in Sri Lanka. This represents a significant gap in the literature. With this background, it would be timely to measure the technical efficiency of smallholder tea plantation in order to identify the potential to increase production without incurring additional cost for inputs. The main objective of this study is to measure the technical efficiency of smallholder tea plantation. The specific objectives are: (a) to identify the factors affecting the technical efficiency of smallholder tea plantation and (b) to suggest some policy recommendation for improving the technical efficiency. 


\section{LITERATURE REVIEW}

According to Farrell (1957) "technical efficiency is defined as the ability to archive a higher level of output given a similar level of inputs, allocative efficiency deals with the extent to which farmers make efficient decisions by using inputs up to the level of which their marginal contribution to production value is equal to the factor costs and technical and allocative efficiencies are component of economic efficiency." An organization said that it is technically efficient if it achieves the maximum output level from a given amount of inputs on the assumption that it is technology stable (Ziechang, 1984; Rawlins, 1989; Battese \& Tessema, 1993; Wijesinghe \& Wijesinghe, 2015). The technical efficiency of an individual decision-making unit is defined as the ratio of observed output to the corresponding frontier output based on the input level used by that firm (Russel, 1985; Battese \& Coelli, 1995). Technical efficiency is an essential condition for allocative efficiency, and allocative efficiency is an essential condition for optimal allocation of resources (Shantha, 2019).

There are two methods in the literature that are commonly used to measure technical efficiency. That is, the Stochastic Frontier Approach (SFA), which is a parametric method, and the Data Envelopment Analysis (DEA) method, which is a non-parametric method. The SFA was originally proposed by three teams of researchers (Aigner et al., 1977; Battese \& Corra, 1977; Meeusen \& Van den Broek, 1977) and they developed it simultaneously as well as independently. The advantage of this is; that it introduces the error term consists of statistical noise, measurement errors and external vibrations outside the control of production units and provides the basis for hypothetical statistical tests of product structure and inefficiency. It also produces good results for single-output and multi-input models (Hong \& Yabe, 2015). But the DEA is not stochastic, and it is not possible to distinguish random and inefficient effects from the error term in calculating technical efficiency. It does not allow for a test of any statistical significance (Shantha, 2019). Battese and Coelli (1995) pointed out that SFA is more suitable than DEA to estimate technical efficiency in agricultural products. 


\section{Model Specification}

The basic specification included a production function specified for cross-sectional data, and the error term consisted of two components. That is, the stochastic random error component and the technical inefficiency component. The model is expressed in the following form:

$Y=f\left(X_{i} \beta\right)+\varepsilon_{i} \quad \mathrm{I}=1, \ldots \ldots \ldots, \mathrm{N}$

Where $Y_{i}$ is the production (or the logarithm of the production) of the $i^{\text {th }}$ firm; $X_{i}=K \times 1$ vector of input quantities of the $i^{\text {th }}$ firm; $\beta=$ vector of unknown parameters.

The essential idea behind the stochastic frontier model is that $\varepsilon_{\mathrm{i}}$ term can be written as:

$\varepsilon_{i}=V_{i}-U_{i}$

$\boldsymbol{V}_{\boldsymbol{i}}=$ the random variable which are assumed to be independently and identically distributed and $\left[\boldsymbol{N}\left(\mathbf{0}, \boldsymbol{\sigma}_{v}^{2}\right)\right]$ independent of the $\boldsymbol{U}_{\boldsymbol{i}}$. This is a twosided component and is a random error with a normal distribution. It captures changes in output due to stochastic influences outside the control of farmers such as input / price fluctuations, weather, natural disasters, diseases, combined effects of undisclosed inputs to production and other external random factors. $\boldsymbol{U}_{\boldsymbol{i}}$ is a one-sided efficiency component that captures the technical efficiency of farmers; this is a non-negative random error. It is often assumed that this will be distributed independently and identically, and that it will be normal or half-normal $\left[\boldsymbol{N}\left(\mathbf{0}, \boldsymbol{\sigma}_{\boldsymbol{u}}^{2}\right)\right]$. The stochastic frontier production function can be estimated using the Maximum Likelihood Method (MLE) or the Corrected Ordinary Least Squares (COLS) method.

In examining the literature on the variables used for the stochastic frontier production function, research groups (Hong \& Yabe, 2015; Katungwe et al., 2017; Priyanath et al., 2018; Kodagoda \& Dharmadasa, 2019) conducted studies on measuring the technical efficiency of small-scale tea plantation, where the tea yield is used as the dependent variable and extent of land, labour and fertilizer are commonly used as independent variables in the stochastic production function. Along with the above common variables, Basnayake and Gunaratne (2002) used chemical and dolomite. 
In examining the literature on the variables used for the technical efficiency function, according to Battese and Coelli (1995) the variables such as the age of farmer, experience, education, occupation, type of crop (VP or seedling) and type of clone were used. In addition to that variables, according to Katungwe et al. (2017) the distance from the farm to the tea factory, age of tea bushes, number of family members, type of contract and access to extension services and according to Kodagoda and Dharmadasa (2019) the variables such as gender, access to livestock, other crops grown, number of members in the household and age of tea bushes were used.

\section{Research Hypotheses}

$\mathrm{H}_{1}$ : Labour and Chemical Fertilizer have a positive impact on tea production.

According to the results of the study of the researchers, (Basnayake \& Gunaratne, 2002; Katungwe et al., 2017; Priyanath et al., 2018) the variables of labour and fertilizer have a significant positive impact on tea production. Hong and Yabe (2015) point out that labour has a positive impact on tea production. In addition to that, according to Kodagoda and Dharmadasa (2019) among the inputs used for the production function, labour elasticity is the highest value and that it has a positive impact on tea production. On this basis, the first hypothesis $\left(\mathrm{H}_{1}\right)$ was developed.

$\mathrm{H}_{2}$ : Gender, Experience, Level of Education and Access to Quality Extension Services have a positive impact on technical efficiency.

According to researchers, Due and Gladwin (1991) and Adesina and Djato (1997), male farmers have the potential to increase output more than female farmers. Hong and Yabe (2015) point out that female farmers do not have access to inputs, loans and extension training, so they spend most of their time on household chores, they often tend to have lower yields because they do not have access to cash or credit to get modern inputs that increase yields. Therefore, the efficiency of female farmers is less than that of male farmers. Many agricultural technologies are designed on the assumption that farm managers are male farmers, thus limiting the productivity of women (Balakrishnan, 2000). 
According to Katungwe et al. (2017) and Kodagoda and Dharmadasa (2019), farmers with more experience in tea cultivation are more efficient than those with less experience. Hong and Yabe (2015) point out that more experienced farmers can better manage existing inputs and achieve higher yields than less experienced farmers.

According to researchers, Katungwe et al. (2017) and Kodagoda and Dharmadasa (2019), there is a positive relationship between education and technical efficiency. That is, educated farmers are more efficient than ignorant farmers. According to Basnayake and Gunaratne (2002) as they acquire knowledge through education, they are more efficient than the ignorant farmers as they are able to make the right decisions and easily manage the tea plantations by grasping the advice given by the extension officers.

According to researchers (Kalirajan, 1991; Xu \& Jeffrey,1998; AIHassan, 2008; Saigenji \& Zeller, 2009; Nyagaka et al., 2010), the technical efficiency of STFs accessing quality extension advice is higher than that of STFs who do not have access to quality extension advice. Hong and Yabe (2015) point out that the accessing to extension services has a positive impact on both input and output-oriented technical efficiencies, extension services such as implying training courses or technical advice on tea cultivation, land preparation, planting, training in fertilizer and pesticide application, training in harvesting and conservation, providing information on the tea market and sales skills will not only help STFs increase production but also save on input usage. The second hypothesis $\left(\mathrm{H}_{2}\right)$ was developed based on the above four relationships.

$\mathrm{H}_{3}$ : Age of Tea Bushes has a negative impact on technical efficiency.

According to Priyanath et al. (2018), there is a negative relationship between age of tea bushes and technical efficiency. But according to researchers, (Hong \& Yabe, 2015; Kodagoda \& Dharmadasa, 2019) the age of tea bushes has a positive impact on technical efficiency. Discussions with tea inspectors and STFs in the study area revealed that the yield of tea bushes gradually decreases after the age of 10 years. Also a significant percentage of the tea cultivations in the selected study area were over 20 years old. Based on those discussions and the previous literature, a third hypothesis $\left(\mathrm{H}_{3}\right)$ was developed. 
H4: Clone type has a positive impact on technical efficiency.

Discussions with tea inspectors revealed that the TRI- 2026 clone is the recommended clone for these study areas and highly productive. Based on that, the fourth hypothesis $\left(\mathrm{H}_{4}\right)$ was developed.

\section{METHODOLOGY}

Most of the STFs in Sri Lanka are spread over $75 \%$ of the low country, including Ratnapura, Galle and Matara districts. This study covered Matara district which has the third-largest number of STFs out of 25 districts in Sri Lanka. Matara district consists of 20 Tea Inspector (TI) ranges.

There are 68,376 STFs in Matara district, and it is the population of this study. Out of three TI Ranges of Pitabeddara, Pasgoda and Kotapola, which have the largest number of STFs in Matara district respectively, a sample of 120 STFs was randomly selected by using a multi-stage sampling method and data was collected through a structured questionnaire. The sample was selected from three TI Ranges in proportion as follows.

Table 1: Sample and Sampling Framework

\begin{tabular}{lll}
\multicolumn{1}{c}{ TI ranges } & \multicolumn{1}{c}{ Number of STFs } & Sample size \\
\hline Pitabeddara & 5,923 & 46 \\
Pasgoda & 5,012 & 39 \\
Kotapola & 4,507 & 35 \\
Total & 15,442 & 120 \\
\hline
\end{tabular}

Source: Survey Data 2020

The variables included in the stochastic production frontier model and the technical efficiency model are defined in Table 2.

Table 2: Variable Definition and Units of Measurements used for the Models

\begin{tabular}{lll}
\hline Variable & Definitions & Units \\
\hline $\mathrm{Y}$ & Tea production & $\mathrm{Kg} / \mathrm{ac}$ \\
$\mathrm{X} 1$ & \\
$\mathrm{X} 2$ & Extent of land & Acre \\
$\mathrm{X} 3$ & Quantity of labour & Man days \\
& Quantity of chemical & $\mathrm{Kg} / \mathrm{ac}$ \\
$\mathrm{X} 4$ & fertilizer & \\
$\mathrm{X} 5$ & Cost of weeding & $\mathrm{Rs} / \mathrm{ac}$ \\
$\mathrm{Z1}$ & Quantity of dolomite & $\mathrm{Kg} / \mathrm{ac}$ \\
$\mathrm{Z2}$ & Gender & Male =1, Female $=0$ \\
& Level of education & Years of schooling
\end{tabular}




\begin{tabular}{lll}
\hline Z3 & $\begin{array}{l}\text { Household members } \\
\text { Experiences of tea } \\
\text { zultivation }\end{array}$ & $\begin{array}{l}\text { Number of members } \\
\text { Number of years }\end{array}$ \\
Z5 & $\begin{array}{l}\text { Access to quality } \\
\text { extension services } \\
\text { Age of tea bushes }\end{array}$ & $\begin{array}{l}\text { Access to quality extension } \\
\text { services }=1 \text {, otherwise }=0\end{array}$ \\
Z7 & $\begin{array}{l}\text { Type of clone } \\
\text { Number of years }\end{array}$ \\
Z8 & $\begin{array}{l}\text { Culty clone TRI-2026 is grown } \\
\text { crops in tea land }\end{array}$ & $\begin{array}{l}\text { Cultivation of other crops in } \\
\text { tea land }=1, \text { otherwise }=0\end{array}$ \\
& & \\
Z9 & $\begin{array}{l}\text { Distance from the farm } \\
\text { to the tea factory }\end{array}$ & Km \\
\hline
\end{tabular}

Note: a man-day unit $=8$ working hours of an adult $\&$ all of the above are annual data. Source: Survey Data 2020

Different types of production functions have been used in the previous literature to discuss stochastic analysis. The most commonly used production function in the empirical literature is Cobb-Douglas production function and Transcendental Logarithm production function (Baten et al., 2009; Battese \& Corra, 1977; Hassan \& Ahmad, 2005; Kachroo et al., 2010). Many researchers have used Cobb-Douglas production function to estimate the technical efficiency of the agricultural sector. Basnayake and Gunaratne (2002) noted that the Cobb-Douglas specification is widely accepted in the literature. This study also uses the Stochastic Frontier Production Model using the CobbDouglas functional form to assess the impact production factors on tea yields and measure technical efficiency. The parameters of inefficiency model were produced with a two-step approach.

The empirical model for Cobb-Douglas function forms is given by:

$$
\ln Y_{i}=\beta_{0}+\sum_{J=1}^{5} \beta_{i j} \ln X_{i j}+V_{i}-U_{i}
$$

Where $\ln$ is the natural logarithm, $\mathrm{Y}_{\mathrm{i}}$ is output of $\mathrm{i}^{\text {th }} \mathrm{STFs}, \mathrm{X}_{\mathrm{i}}$ 's are input variables presented in Table $2, \beta$ s are unknown parameters to be estimated, and $\mathrm{V}_{\mathrm{i}}=$ random error, $\mathrm{U}_{\mathrm{i}}=$ technical inefficiency term. 


\section{Technical Efficiency Model}

Since the technical efficiency values are between 0 and 1 , the Tobit model (Censored regression) was used to identify the factors affecting technical efficiency, as the ordinary least squares (OLS) method often biased results. The technical efficiency model is estimated from the following equation.

$\mathrm{TEi}=\delta_{0}+\delta_{1} Z_{1}+\delta_{2} Z_{2}+\delta_{3} Z_{3}+\delta_{4} Z_{4}+\delta_{5} Z_{5}+\delta_{6} Z_{6}+\delta_{7} Z_{7}+\delta_{8} Z_{8}+\delta_{9} Z_{9}+W_{i}$

$\mathrm{Z}_{\mathrm{i}}$ is a vector of variables which may determine the technical efficiency of the $i^{\text {th }}$ STFs and operational variables defined in Table 2 and $\delta$ is a vector of efficiency parameters to be estimated, and $\omega_{\mathrm{i}}$ is the random error term. The stochastic frontier production model and Tobit model were estimated through StataMP13 (64 bit) software.

\section{RESULTS AND DISCUSSION}

\section{Descriptive Statistics}

According to Table 3, the average annual profit per acre of STFs is Rs. $325,212.3$ and the variability index is $63.17 \%\{(205,431.9 / 325,212.3) * 100\}$. The gross profit margin is $59.12 \%\{(325,212.3 / 550,081.9) * 100\}$. The average annual yield was $4,780.45$ per acre, and the variability index was $56.45 \%$. Thus it appears that there is a large yield difference between STFs. This is mainly due to input inequality. The average price of per $\mathrm{kg}$ of tea leaves is Rs. 109.46 and STFs noted that tea leaf prices are subject to frequent fluctuations. The highest and lowest annual tea yields were revealed in the Pitabeddara and Kotapola TI Ranges. A large proportion of labour costs of the selected sample represented family labour.

Table 3: Descriptive Statistics

\begin{tabular}{lllll}
\hline Variables & Mean & $\begin{array}{l}\text { Std. } \\
\text { Deviation }\end{array}$ & $\begin{array}{l}\text { Minimum } \\
\text { value }\end{array}$ & $\begin{array}{l}\text { Maximum } \\
\text { value }\end{array}$ \\
\hline $\mathrm{Y}$ & $4,780.45$ & $2,698.61$ & 384 & 12,000 \\
\hline $\mathrm{X} 1$ & 1.29 & 1.01 & 0.25 & 8 \\
\hline $\mathrm{X} 2$ & 171.36 & 92.67 & 18 & 480 \\
\hline $\mathrm{X} 3$ & 530.63 & 357.26 & 50 & 1,600 \\
\hline $\mathrm{X} 4$ & $29,495.13$ & $18,778.19$ & 1,250 & 96,000 \\
\hline $\mathrm{X} 5$ & 145.62 & 226.93 & 0 & 1,200 \\
\hline Price of tea (Rs/per Kg) & 109.46 & 1.81 & 102 & 115 \\
\hline Total cost of production (Rs/ac) & $224,869.6$ & 107,337 & 32,575 & 513,725 \\
\hline Gross income (Rs/ac) & $550,081.9$ & $293,588.3$ & $82,032.64$ & $133,852,0$ \\
\hline Profit (Rs/ac) & $325,212.3$ & $205,431.9$ & $14,539.93$ & $865,136.7$ \\
\hline Source: Survey Data 2020 & & & &
\end{tabular}

Source: Survey Data 2020 


\section{Stochastic Frontier Analysis}

Multicollinearity and heteroskedasticity are two major problems in estimating the production frontier. The results from Variance Inflation Factor (VIF) and Breusch-Pagan/Cook-Weisberg test showed that neither multicollinearity (mean value of VIF $=1.37<10$ ) nor heteroskedasticity (probability of chi-square statistic is 1.54 , accepting the null hypothesis of constant variance) was found in the model.

According to Table 4, all variables in the Cobb-Douglas production function have a statistically significant effect on tea production, according to the estimated MLE results. Here, the MLE coefficients show the elasticity coefficients which are directly related to the inputs of tea product. This implies that tea yields have increased by $0.063 \%, 0.843 \%, 0.170 \%, 0.108 \%$ and $0.021 \%$, respectively, by increasing the extent of land, labour, chemical fertilizer, weeding costs and dolomite by $1 \%$, while all other inputs affecting the tea yield remained stable.

According to the below results, labour elasticity is higher than other inputs in small scale tea cultivation in the study area. That is, labour is the most important factor influencing the smallholder tea plantation and it was revealed that according to the selected sample, a large percentage of STFs use family labour to harvest tea. This result is consistent with the results of the (Kodagoda \& Dharmadasa, 2019).

Here, weed control costs were considered as chemical weed control costs and labour costs for hoeing. Most of the STFs in the selected sample were weed controlled by hoeing. According to this study, there is a positive relationship between dolomite and tea yields, and the results show that the proper application of dolomite, which correctly identifies the $\mathrm{PH}$ value content of the soil, can increase tea production. However, according to Basnayake and Gunaratne (2002) dolomite had a negative impact on tea production.

Also, the sum of the elasticity coefficients was 1.205 , indicating that there is an increasing return to scale and that tea production was in stage I of the production function. It also implies that the proportionate increase of the inputs could increase output by a relatively greater proportion. According to Adedeji et al. (2011), the increasing returns to scale of production indicate that farmers have not yet achieved optimal efficiency, which indirectly indicates 
technical inefficiency. This means that policies need to be put in place to use existing resources efficiently to make STFs more productive and profitable entrepreneurs.

Table 4: Results of Stochastic frontier analysis

\begin{tabular}{|c|c|c|c|c|}
\hline Variables & Parameter & Coefficient (MLE) & Standard Error & Z-ratio \\
\hline Constant & $\beta_{0}$ & $2.146^{* * *}$ & 0.405 & 5.30 \\
\hline $\operatorname{Ln} X_{1}$ & $\beta_{1}$ & $0.063^{*}$ & 0.037 & 1.70 \\
\hline $\operatorname{Ln} X_{2}$ & $\beta_{2}$ & $0.843^{* * *}$ & 0.051 & 16.53 \\
\hline $\operatorname{Ln} X_{3}$ & $\beta_{3}$ & $0.170^{* * *}$ & 0.039 & 4.30 \\
\hline $\operatorname{Ln} \mathrm{X}_{4}$ & $\beta_{4}$ & $0.108^{* * *}$ & 0.042 & 2.61 \\
\hline $\operatorname{Ln} \mathrm{X}_{5}$ & $\beta_{5}$ & $0.021^{*}$ & 0.012 & 1.73 \\
\hline $\begin{array}{l}\text { Sigma Square } \\
\qquad\left(\boldsymbol{\delta}_{u}^{2}+\boldsymbol{\delta}_{v}^{2}\right)\end{array}$ & $\delta^{2}$ & 0.147 & & \\
\hline $\begin{array}{l}\text { Log Likelihood } \\
\text { Function }\end{array}$ & -17.525 & & & \\
\hline Sigma & $\delta$ & 0.383 & & \\
\hline Sigma-Squared (u) & $\delta_{\mathrm{u}}^{2}$ & 0.106 & & \\
\hline Sigma-Squared (v) & $\delta_{\mathrm{v}}^{2}$ & 0.041 & & \\
\hline Lamda $\left(\boldsymbol{\delta}_{\boldsymbol{u}} / \boldsymbol{\delta}_{\boldsymbol{v}}\right)$ & $\lambda$ & 1.601 & & \\
\hline $\begin{array}{l}\text { Gamma } \\
\qquad\left(\boldsymbol{\delta}_{\mathbf{u}}^{2} / \boldsymbol{\delta}^{2}\right)\end{array}$ & $\gamma$ & 0.721 & & \\
\hline
\end{tabular}

Likelihood-ratio test of sigma_u=0: chibar $2(01)=1.31$ Prob $>=$ chibar2 $=0.126$

Note: $* * *, * *, *$ significant at $1 \%, 5 \%$ and $10 \%$ respectively

Source: Survey Data 2020

The existence of inefficiency component in the stochastic frontier model for STFs was tested using the likelihood-ratio test. A null hypothesis that there were no inefficiencies in the model $\left(\mathrm{H}_{\mathrm{o}}\right.$ : sigma_u $\left.\mathrm{u}=0\right)$ was rejected at $5 \%$ level as shown in Table 4. This implied that the inefficiency variation (sigma_u) was significantly different from zero, hence worth measuring. It further implied that the frontier was not deterministic but rather stochastic in nature. This finding led to rejection of the null hypothesis and concluded that STFs in Matara district are not technically efficient.

The $\gamma$ is the percentage of the variance of firm-specific technical inefficiency $\left(\mathrm{U}_{\mathrm{i}}\right)$ to the total variance of output. Since, $\gamma$ is close to $1(0.721)$ suggested that the technical inefficiency exists with small scale tea plantation in Matara District. It also important to note that a very high percentage of the variance of the error term is represented by an inefficiency error $\left(U_{i}\right)$ and not by random error $\left(\mathrm{V}_{\mathrm{i}}\right)$. That is, it is clear that the inefficiency error component 
makes a significant contribution to the analysis. Further, $\lambda$ is the ratio of the variance of firm-specific technical inefficiency $\left(\mathrm{U}_{\mathrm{i}}\right)$ to the variance of random error $\left(\mathrm{V}_{\mathrm{i}}\right)$. A positive value of $\delta=0.383$ according to the above results means that the observed output deviates from the frontier output.

According to Table 5, the technical efficiency of selected STFs ranges from $49.51 \%$ to $92.86 \%$ and the average technical efficiency is $78.44 \%$. This indicates that production can be further increased by 21.56 per cent without increasing the level of input. Besides, it indicates that average tea farmer in the sample could save 15.5 per cent (i.e., $1-\{78.44 / 92.86\}$ ) of cost and the most technically inefficient tea farmer can achieve 50.5\% (100 - 49.51) cost saving compared with the TE level of his most efficient tea farmer. In addition, around 0.83 per cent firms reflect very poor TE (less than 50\%) and $48.5 \%$ firms are keeping an excellent record in TE (more than $80 \%$ ).

Table 5: Frequency distribution of technical efficiency

\begin{tabular}{lll}
\hline Range of Technical Efficiency & Number of STFs & Percentage (\%) \\
\hline$<50$ & 1 & 0.83 \\
\hline $51-60$ & 6 & 5 \\
\hline $61-70$ & 19 & 15.83 \\
\hline $71-80$ & 37 & 30.83 \\
\hline $81-90$ & 53 & 44.17 \\
\hline $91-100$ & 4 & 3.33 \\
\hline Maximum TE $=92.86 \%$ & 120 & 100 \\
Minimum TE $=49.51 \%$ & & \\
Mean TE $=78.44 \%$ & &
\end{tabular}

Source: Survey Data 2020

\section{Factors Affecting Technical Efficiency}

Nine variables were selected for the Tobit model as explanatory variables, including the socio-economic factors of STFs and several other important variables related to small scale tea cultivation. Of those, five variables are continuous, and four variables are dummy variables. According to Table 6, variables such as education, experience, tea age, and all dummy variables have a significant impact on the technical efficiency and revealed that the level of education has a greater impact on technical efficiency than the experience of tea cultivation. The coefficients corresponding to the dummy variables were interpreted in terms of exponentiated coefficients. According to researchers (Hair et al., 2010; Shantha et al., 2013), exponential coefficients are the best way to interpret the effect of dummy variables. 
The exponentiated coefficient of $\propto_{1}$ is 1.12 means that the TE score of male STFs have a 12 percent higher TE score than female STFs (1.12-1*100). Similarly, the TE score of STFs accessing quality extension advice is $10 \%$ higher than that of STFs who do not have access to quality extension advice. The TE score of those who other crops grow is $3 \%$ lower than those who do not grow other crops in the tea land. The TE score of those who use the Clone TRI-2026 is $2 \%$ higher than that of STFs who do not use that clone. Finally, gender and access to quality extension services were identified as variables that have a greater impact on the technical efficiency of small-scale tea cultivation in the study area.

Table 6: Technical efficiency model - Tobit regression (dependent variable - technical efficiency)

\begin{tabular}{lcllll}
\hline \multicolumn{1}{c}{ Variables } & Parameter & Coefficient & Standard error & T-Ratio & Exp $(\alpha)$ \\
\hline Constant & $\propto_{0}$ & $0.5930^{* * *}$ & 0.03583 & 16.55 & \\
\hline$Z_{1}$ & $\propto_{1}$ & $0.1155^{* * *}$ & 0.0165 & 6.97 & 1.12 \\
\hline$Z_{2}$ & $\propto_{2}$ & $0.0040^{* * *}$ & 0.0015 & 2.57 & 1.00 \\
\hline$Z_{3}$ & $\propto_{3}$ & -0.0013 & 0.0040 & -0.33 & 0.99 \\
\hline$Z_{4}$ & $\propto_{4}$ & $0.0007^{*}$ & 0.0004 & 1.63 & 1.00 \\
\hline$Z_{5}$ & $\propto_{5}$ & $0.1019^{* * *}$ & 0.0158 & 6.44 & 1.10 \\
\hline$Z_{6}$ & $\propto_{6}$ & $-0.0010^{*}$ & 0.0005 & -1.77 & 0.99 \\
\hline$Z_{7}$ & $\propto_{7}$ & $0.0215^{*}$ & 0.0125 & 1.72 & 1.02 \\
\hline$Z_{8}$ & $\propto_{8}$ & $-0.0302^{* * *}$ & 0.0108 & -2.79 & 0.97 \\
\hline$Z_{9}$ & $\propto_{9}$ & -0.00003 & 0.0004 & -0.09 & 0.99 \\
\hline Log Likelihood & & 187.82875 & & & \\
Function & & & & &
\end{tabular}

Source: Survey Data 2020

\section{Outcome of Hypotheses Testing}

$\mathrm{H}_{1}$ : Labour and Chemical fertilizer have a positive impact on tea production.

According to the results of the study, the variables of labour and chemical fertilizers have a positive impact on tea production. Thus, the first hypothesis $\left(\mathrm{H}_{1}\right)$ is accepted.

$\mathrm{H}_{2}$ : Gender, Experience, Level of Education and Access to Quality Extension Services have a positive impact on technical efficiency.

According to the results of the study, male STFs are more efficient than female STFs. Also, STFs with more experience are more efficient than STFs with less experience, and educated farmers are more efficient than ignorant 
farmers. Furthermore, farmers who access extension services are more efficient than those who do not have access to extension services. Thus the second hypothesis $\left(\mathrm{H}_{2}\right)$ is accepted.

$\mathrm{H}_{3}$ : Age of tea bushes has a negative impact on technical efficiency.

According to the results of the study, the variable of age of tea bushes has a negative impact on technical efficiency. That is, the third hypothesis $\left(\mathrm{H}_{3}\right)$ is accepted.

$\mathrm{H}_{4}$ : Clone type has a positive impact on technical efficiency

According to the results of the study, technical efficiency of those who use the Clone TRI-2026 is higher than that of STFs who do not use that clone. That is, the fourth hypothesis $\left(\mathrm{H}_{4}\right)$ is accepted.

\section{CONCLUSION}

The main purpose of this study is to measure the technical efficiency of Smallholder Tea Plantation in Sri Lanka. According to frontier results, the average technical efficiency of selected STFs is 78 per cent. This indicates that production can be further increased by 22 per cent without increasing the level of input. Variables of land, labour, chemical fertilizer, weeds control cost and dolomite have a significant positive impact on tea yield and labour is the most important factor for tea production. A large percentage of STFs used family labour for tea harvesting. It was also observed that STFs were increasingly focused on the use of fertilizers. Although farmers believed that the higher the yield of chemical fertilizers, discussions with tea officials revealed that although the application of tea fertilizer increased the yield, it had an adverse effect not only on the quality of the tea harvest but also on the environment and the lives of plants and animals, including humans. Therefore, STFs should be advised to reduce their dependence on chemical fertilizers and focus on the use of organic fertilizers. Furthermore, it was revealed that a large percentage of STFs control weeds by hoeing and the use of herbicides is kept to a minimum. That is, STFs should be further encouraged to control weeds through hoeing as the use of herbicides has adverse effects. 
According to the results of a descriptive analysis of the study, the percentage of males among STFs was much higher than that of females. The majority of STFs are older and middle-aged, while the younger generation is less interested in tea cultivation. Due to declining income from tea cultivation, price fluctuations and unfavourable climatic conditions affecting the tea cultivation, it is unsafe to engage in tea cultivation full time and low social acceptance the younger generation will not have access to tea cultivation but will have access to another job. Therefore, government agencies involved in the smallholding tea sector should intervene and introduce a reasonable guaranteed price for tea leaves and inputs. Also, programs should be organized through Small Tea Development Societies to provide the necessary advice to direct the unemployed youth to tea cultivation to prevent labour shortage and to encourage the younger generation to engage in tea cultivation with older farmers.

Also, although STFs have a secondary level of education and significantly higher experience in tea cultivation, considering their average tea cultivation area, it is evident that their cultivation is limited to less than 2 acres. This means that even though they have the knowledge to develop tea cultivation, they do not utilize it to its full potential. That is, the government should provide land to tea growers to increase the area under tea cultivation and provide necessary advice and facilities for tea cultivation on lands abandoned by growers. Also, a large percentage of small tea lands in the study area are over 20 years old, which indicates that the re-plantation of STFs in the study area is at a very low level. That is, STFs should be encouraged to replant, and the subsidy for it should be increased, and Microfinance Credit Schemes should be introduced for tea cultivation. Furthermore, providing selfemployment to cover the income lost to STFs due to replanting. According to the selected sample, although a significant percentage of the farmers were members of the societies, the participation of the societies was meagre.

According to the results of the Tobit regression, the variables such as gender, education, access to extension services, experience and clone type have significant positive impact and variables in the tea age and other crops grown also have a significant negative impact on technical efficiency. In variables of experience and level of education, the level of education has a greater impact on technical efficiency than the experience of tea cultivation. That is, the educational facilities in the study area should be further improved. Gender and access to quality extension services were identified as the 
variables that have the greatest impact on technical efficiency. That is, male STFs are more efficient than female STFs. Therefore, further encouragement of male farmers to focus on tea cultivation and since most programs are designed with farm managers as men, women-oriented programs should also be implemented to increase women's participation in tea cultivation and increase their efficiency.

According to the study results, respective authorities need to be further strengthened the extension services on fertilizer application, pruning, technical knowledge, nursery management, pest and disease management through Tea Small Holdings Development Societies and new strategies should be formulated to involve farmers who do not participate in the societies. (E.g. adopting strategies such as providing tea plants and subsidizing farmers participating in societies). In addition to that, a proper system should be followed to introduce tea inspectors to the relevant area and monitor their role.

In addition to that, it can be recommended that the TRI-2026 clone is suitable for the study area. Discussions with tea officials revealed that although the yield of the TRI-2025 clone was lower than that of the TRI-2026, the plant survival of the TRI-2025 clone was higher. This means that the TRI2025 clone has the potential to withstand adverse weather conditions such as drought. Therefore, the TRI -2025 clone is also recommended for this area. The efficiency of those who other crops grow is lower than those who do not grow other crops in the tea land. That is, STFs should be properly advised on how to manage properly between crops so that all inputs, including labour, can be highly productive without adversely affecting tea cultivation.

\section{REFERENCES}

Adedeji, I. A., Ajetomobi, J. O., \& Olapade-Ogunwole, F. (2011). Technical efficiency of cocoa production in Oyo State, Nigeria. Continental Journal of Agricultural Economics, 5(1), 30-40.

Adesina, A., \& Djato, K. (1997). Relative efficiency of women as farm managers: Profit function analysis in Côte d'Ivoire. Agricultural Economics, 16(1), 47-53.

Aigner, D., Lovell, C. K., \& Schmidt, P. (1977). Formulation and estimation of stochastic frontier production function models. Journal of Econometrics, 6(1), 21-37. 
Al-Hassan, D. (2008). Technical Efficiency of Rice Farmers in Northern Ghana. African Economic Research Consortium, Nairobi.

Ali, M., \& Chaudhry, M. A. (1990). Inter-regional farm efficiency in Pakistan's Punjab: a frontier Production function study. Journal of Agricultural Economics, 41(1), 62-74.

Balakrishnan, R. (2000). Widening gaps in technology development and technology transfer to support rural women. Human resources in agricultural and rural development, 80-91.

Basnayake, B., \& Gunaratne, L. (2002). Estimation of Technical Efficiency and Its Determinants in the Tea Small Holding Sector in the Mid Country Wet Zone of Sri Lanka. Sri Lankan Journal of Agricultural Economics, 24(3), 137-150.

Baten, M. A., Kamil, A. A., \& Haque, M. A. (2009). Modeling technical inefficiencies effects in a stochastic frontier production function for panel data. African Journal of Agricultural Research, 4(12), 1374-1382.

Battese, G., \& Coelli, T. (1995). A Model for Technical Inefficiency Effects in a Stochastic Frontier Production Function for Panel Data. Empirical Economics, 20(2), 325-332.

Battese, G. E., \& Corra, G. S. (1977). Estimation of a production frontier model: with application to the pastoral zone of Eastern Australia. Australian Journal of Agricultural Economics, 21(3), 169-179.

Battese, G., \& Tessema, G. (1993). Estimation of Stochastic Frontier Production function with time-varying parameters and technical efficiencies using panel data from Indian villages. Agricultural Economics, 9(3), 313-333.

Central Bank of Sri Lanka (CBSL). (2016). Annual Report - 2016.

Central Bank of Sri Lanka (CBSL). (2017). Annual Report - 2017.

Central Bank of Sri Lanka (CBSL). (2019). Annual Report - 2019. 
Due, J., \& Gladwin, C. (1991). Impacts of structural adjustment programs on African women farmers and female-headed households. American Journal of Agricultural Economics, 73(5), 1431-1439.

Farrell, M. (1957). The Measurement of Productive Efficiency. Journal of the Royal Statistical Society: Series A (General), 120(3), 253-281.

Fernando, C. (2016). Tea Smallholdings Sector in Sri Lanka. Tea Small Holdings Development Authority: Sri Lanka.

Hair, J. F., Black, W. C., Babin, J. B., \& Anderson, R. E. (2010). Multivariate Data Analysis. Englewood Cliffs, NJ: Prentice Hall

Hassan, S., \& Ahmad, B. (2005). Stochastic frontier production function, application and hypothesis testing. International Journal of Agriculture and Biology, 7(3), 427-430.

Hong, N. B., \& Yabe, M. (2015). Resource use efficiency of tea production in Vietnam: Using translog SFA model. International Journal of Biology, 7(9), 160.

Kachroo, J., Sharma, A., \& Kachroo, D. (2010). Technical efficiency of dryland and irrigated wheat based on stochastic model. Agricultural Economics Research Review, 23(2), 383-390.

Kalirajan, K. P. (1991). The importance of efficient use in the adoption of technology: a micro panel data analysis. Journal of Productivity Analysis, 2(2), 113-126.

Katungwe, F., Elepu, G., \& Dzanja, J. (2017). Technical Efficiency of Smallholder Tea Production in South-Eastern Malawi: A Stochastic Frontier Approach. Journal of Agricultural Sciences-Sri Lanka, 12(3), 185-196.

Kodagoda, A., \& Dharmadasa, R. (2019). Technical efficiency of organic tea smallholders: evidence from Uva region of Sri Lanka. http://ir.lib.seu.ac.lk/handle/123456789/3940

Meeusen, W., \& Van de Broeck, J. (1977). Efficiency Estimation from CobbDouglas Production Functions with Composed Error. International Economics Review, 435-444. 
Mohamed, M. Z., \& Zoysa, A. K. N. (2006). Current status and future research focus of tea in Sri Lanka. Journal of Agricultural Sciences-Sri Lanka, 2(2).

Nyagaka, D. O., Obare, G. A., Omiti, J. M., \& Nguyo, W. (2010). Technical efficiency in resource use: Evidence from smallholder Irish potato farmers in Nyandarua North District, Kenya. African Journal of Agricultural Research, 5(11), 1179-1186.

Priyanath, H. M. S., Premaratne, S. P., Yoosuf, A., \& Maurice, D. (2018). Technical Efficiency for Tea Smallholder Farmers under UTZ Certification System in Sri Lanka: A Stochastic Frontier Approach. SEISENSE Journal of Management, 1(2), 1-19.

Rawlins, G. (1989). A Model to Measure Achieved Levels of Technical Efficiency of African Farmers. CERAF, Montclair State University, New Jersey, 336.

Russel, R. (1985). Measurement of Technical Efficiency. Journal of Economic Theory, 35(1), 109-126.

Saigenji, Y., \& Zeller, M. (2009, August). Effect of contract farming on productivity and income of small holders: The case of tea production in north-western Vietnam. Paper presented at International Association of Agricultural Economists Conference, Beijing, China

Samaraweera, G. C., Ping, Q., \& Yanjun, L. (2013). Promoting tea business in the tea smallholding sector in developing countries through efficient technology transfer system: Special reference to Sri Lanka. African Journal of Business Management, 7(22), 2186-2194.

Shantha, A. A., Asan Ali, B. G. H., \& Bandara, R. A. G. (2013). Technical efficiency of paddy farming under major irrigation conditions in the dryzone of Sri Lanka: a parametric approach. Australian Journal of Basic and Applied Sciences, 7(6), 104-112.

Shantha, A. A. (2019). Stochastic Frontier Analysis: Theory and Applications. LAMBERT Academic Publishing. 
Tadesse, B., \& Krishnamoorthy, S. (1997). Technical efficiency in paddy farms of Tamil Nadu: an analysis based on farm size and ecological zone. The Journal of the International Association of Agricultural Economists, 16(3), 185-192.

Tea Smallholder Development Authority, Sri Lanka (TSHDA). (2017). Annual Report.

Wijesinghe, P., \& Wijesinghe, R. (2015). Technical Efficiency of Paddy Farming in Low Country Wet Zone. Hector Kobbekaduwa Agrarian Research and Training Institute.

Xu, X., \& Jeffrey, S. R. (1998). Efficiency and technical progress in traditional and modern agriculture: evidence from rice production in China. Agricultural Economics, 18(2), 157-165.

Ziechang, K. (1984). An extended Farrell Efficiency Measure. Journal of Economic Theory, 33(2), 387-396. 